\title{
Danian/Selandian boundary stratigraphy, paleoenvironment and Ostracoda from Sidi Nasseur, Tunisia
}

\author{
Jimmy Van Itterbeeck ${ }^{\mathrm{a}, *}$, Jorinde Sprong ${ }^{\mathrm{a}}$, Christian Dupuis ${ }^{\mathrm{b}}$, \\ Robert P. Speijer ${ }^{\mathrm{a}}$, Etienne Steurbaut ${ }^{\mathrm{a}, \mathrm{c}}$ \\ a Department of Geography and Geology, KULeuven, Celestijnenlaan 200E, 3001 Leuven, Belgium \\ ${ }^{\mathrm{b}}$ GFA, Faculté Polytechnique de Mons, 9 Rue de Houdain, 9000 Mons, Belgium \\ ${ }^{c}$ Royal Belgian Institute of Natural Sciences, Vautierstraat 29, 1000 Brussel, Belgium
}

Received 30 January 2006; received in revised form 26 July 2006; accepted 8 August 2006

\begin{abstract}
Two detailed records (NSF and 05NSC, Sidi Nasseur, Tunisia) across the Danian/Selandian (D/S) boundary were investigated for their micropaleontological content. Calcareous nannofossils and planktic foraminifera provided a biostratigraphic framework. The interval spans part of planktic foraminiferal Zone P2, Subzone P3a and part of Subzone P3b. This corresponds to calcareous nannoplankton Zone NP4. Using a more detailed nannofossil zonation the studied section spans part of Zone NTp6, Zone NTp7a and part of NTp 7b. Quantitative ostracod and qualitative benthic foraminiferal data were used to characterize environmental changes across the $\mathrm{D} / \mathrm{S}$ boundary. The two subsections have yielded a total of 50 ostracod taxa. The ostracod assemblage of the entire section belongs to the Southern Tethyan Type showing subtle but distinct changes up section. Based on statistical analysis of the quantitative ostracod data, faunal changes at a glauconitic maker bed ( $\mathrm{P} 3 \mathrm{a} / \mathrm{P} 3 \mathrm{~b}$ boundary) were demonstrated. The local Reticulina proteros assemblage, with the typical species $R$. proteros, Oertliella vesiculosa and Cytheroptheron lekefense, is gradually replaced by the Protobuntonia nakkadii assemblage, with the typical species Cristaeleberis arabii, Xestoleberis tunisiensis, Cytheropteron sp. and P. nakkadii, across the glauconitic bed. The benthic foraminifera also demonstrated distinct changes at this marker bed. The changes in ostracods and foraminifera are related to changes in paleoproductivity and an overall relative sea-level fall.

The lithological and faunal changes at the $\mathrm{P} 3 \mathrm{a} / \mathrm{P} 3 \mathrm{~b}$ zone boundary within the Sidi Nasseur sections seem to correspond to the $\mathrm{D} / \mathrm{S}$ boundary in the type region in Danmark and are characterized by a significant hiatus, yielding this section not suitable as a GSSP candidate for this boundary.
\end{abstract}

(C) 2006 Elsevier B.V. All rights reserved.

Keywords: Danian/Selandian boundary; Tunisia; Tethys; Ostracoda; Benthic foraminifera

* Corresponding author. Current affiliation: Exploration geologist, Shell International Exploration and Production, Kesslerpark 1, 2288GS Rijswijk, The Netherlands. Tel.: +31 704473722.

E-mail addresses: jvanitterbeeck@yahoo.co.uk (J. Van Itterbeeck), jorinde.sprong@geo.kuleuven.be (J. Sprong), christian.dupuis@fpms.ac.be (C. Dupuis), robert.speijer@geo.kuleuven.be ( $\bar{\equiv}$ peijer), etienne.steurbaut@naturalscience.v. Steurbaut).

\section{Introduction}

Since its definition by Schimper (1874), the Paleocene Series has been a subject of discussion. For a long time, it met with opposition before being internationally accepted as the lowermost series of the Paleogene. Its subdivision has also been the subject of much controversy (Gradstein et al., 2004, fig. 1.7b for an overview). 